\title{
Durkheim's and Simmel's reactions to antisemitism and their reflection in their views on modern society
}

If one ever asked oneself what sociology is all about, one could do worse than consulting Auguste Comte's 1822 manifesto, Prospectus des travaux scientifiques nécessaires pour réorganiser la societé, the Plan of the Scientific Works Necessary for the Reorganization of Society. ${ }^{1}$ It sketches out the historical-structural task that the new discipline, whose name Comte later popularized, was supposed to fulfil, namely to end-but-preserve-as the Germans would say, aufzuheben-the Revolution: safeguard its achievements from reaction as well as from further revolutions. Sociology would do so by separating the good bits of modernity from the bad bits. The former Comte saw as grounded in a secular, macrohistorical trend of European history and civilization, the latter in the undisciplined hubris of troublemakers led astray by metaphysical nonsense peddled by the Enlightenment, or more precisely, by the non-positivistic strand of the Enlightenment. Sociology would study and understand the laws of history and silence the metaphysical troublemakers.

Sociology's commitment to making that messy thing called society safe for modernity (the industrial-capitalist world system of nation states constituted and populated by modern individuals) remained tricky. Spanners were thrown into the machinery left, right, and centre by people who were not so positive about the positive state of society. Rather ironically, most of those who continued and developed the Comtean project of sociology did so by basing it on some of those ghastly metaphysical ideas from the Enlightenment, notably those of Immanuel Kant. Sociology, at least in France and Germany, emerged mostly as a set of differing blends of positivism and Kantian, or neo-Kantian, idealism. Even more ironic, though, is the fact that there were some admirers and followers of at least some aspects of Comte's philosophy who were rather hostile to the progressivist, more liberal project into which positivism as sociology had morphed

1 Auguste Comte, Plan of the Scientific Work Necessary for the Reorganization of Society, in: Idem, Early Political Writings (Cambridge Texts in the History of Political Thought), Cambridge 1998, p. 47-144. 
in the course of the nineteenth century: these figures, including the proto-fascist Charles Maurras and the more mainstream Ferdinand Brunetière, an intellectual cheerleader of the anti-Dreyfusards who was at the receiving end of a most famous polemic by the leading Dreyfusard Emile Durkheim. ${ }^{2}$ Those who shaped the new discipline that Comte had postulated were very much at odds with those anti-liberal Comteans in questions concerning the nature and desirability of modernity. This constellation illustrates the more general point that philosophical and social-theoretical ideas about modernity tend to cut across political divides, and this element of ambiguity must be central to studying them, at least for those who study with a political mind.

The new social order that emerged in the period following the French Revolution was subjected to forms of critique that were (explicitly or implicitly) affirmative of its modern, Enlightenment premises while pointing to their insufficient actualization, and others, sometimes dubbed the 'critique of civilization', or 'cultural critique'-Kulturkritik - that challenged, or claimed to challenge, these premises themselves. ${ }^{3}$ In empirical reality there is no clear demarcation between these two registers of critique, and one could probably describe any modern manifestation of critique as being primarily one of these but at the same time, to a smaller or larger extent, also the other. Sociology, in keeping with Comte's original vision of it, is first of all pitted against the Kulturkritik that it had to do battle with, while both were in turn challenged by Marxism. ${ }^{4}$ To what extent sociology, the science of post-Revolutionary societal consolidation, was, and arguably is, also a bit like its own and the Revolution's enemies, is the question I try to address in this chapter.

For historical reasons that have little to do with Jews, the enemies of the civilization that according to Comte had just entered its positive state often

2 Michael Sutton, Nationalism, Positivism and Catholicism. The Politics of Charles Maurras and French Catholics 1890-1914 (Cambridge Studies in the History and Theory of Politics), Cambridge 1982; Olivier Dard, Charles Maurras. Le maitre et l'action (Nouvelles biographies historiques), Paris 2013.

3 On the concept of Kulturkritik see Georg Bollenbeck, Eine Geschichte der Kulturkritik. Von Rousseau bis Günther Anders, Munich 2007; Rita Aldenhoff, Kapitalismusanalyse und Kulturkritik. Bürgerliche Nationalökonomen entdecken Karl Marx, in: Gangolf Hübinger/Wolfgang J. Mommsen (ed.), Intellektuelle im Deutschen Kaiserreich, Frankfurt a. M. 1993, p. 78-94, 218-222; Ludger Heidebrink, Der Kampf des Bürgers gegen sich selbst. Antinomien moderner Kulturkritik, in: Bernd Wirkus (ed.), Die kulturelle Moderne zwischen Demokratie und Diktatur. Die Weimarer Republik und danach, Konstanz 2007, p. 153-175; Johannes Heinssen, Historismus und Kulturkritik. Studien zur deutschen Geschichtskultur im späten 19. Jahrhundert, Göttingen 2003.

4 The sociologists tended to reject Marxism as either a form of über-metaphysical magic thinking, as for example Simmel did who understood it as a form of Hegelianism, or, to the contrary, as a kind of über-utilitarianism corrosive of society, as most others did. Both are partially correct perceptions of the Marxism of the time. 
thought of it as being somehow Jewish. The rejection of, or resentment against, post-Enlightenment modern civilization took therefore often the form of antisemitism. In Germany and France in the period of the formation of classical sociology two key events in the history of antisemitism in particular stood out in occupying the minds of intellectuals including those who were engaged in the process of theorizing modern society, the Berlin Antisemitism Dispute of 1879 to 1881 in which notables of German national liberalism reacted to the emergence of organized forms of political antisemitism, ${ }^{5}$ and, on a much larger, truly national scale, the Dreyfus affair in France from 1894 to 1906, whose most widely discussed phase began in 1898 when leading intellectuals reacted to the captain's sentencing. ${ }^{6}$

The Berlin Antisemitism Dispute centred on Heinrich von Treitschke's expressions of support for the antisemitic movement whose critics included Moritz Lazarus, an important figure in the development of the social sciences in Germany and a major influence on Georg Simmel, ${ }^{7}$ and liberal notables like Max Weber's father Max Weber Sr. Treitschke's lectures were large events that many Berlin students with an interest in society, politics and history would have attended. It seems safe to assume that no one in the milieu out of which classical sociology emerged in Germany could have been unaware of the dispute on antisemitism, and yet the canonical texts contain practically nothing on it. The case is somewhat different in France where the (in retrospect) undisputed father figure of the discipline, Emile Durkheim, was not only practically and crucially involved in the battle against the antisemitic attack on the republic but intervened very publicly with one of his best-known essays into the affair, "L'individualisme et les intellectuels", 'Individualism and the Intellectuals', em-

5 Marcel Stoetzler, Cultural Difference in the National State. From Trouser-Selling Jews to Unbridled Multiculturalism, in: Patterns of Prejudice 42/3 (2008), p. 245-279; Marcel Stoetzler, The State, the Nation, and the Jews. Liberalism and the Antisemitism Dispute in Bismarck's Germany, Lincoln, London 2008.

6 Stephen Wilson, Ideology and Experience. Antisemitism in France at the Time of the Dreyfus Affair (The Littman Library of Jewish Civilization), Rutherford 1982; Chad Alan Goldberg, Introduction to Emile Durkheim's "Anti-Semitism and Social Crisis," in: Sociological Theory 26,4 (2008), p. 299-321; Idem, The Jews, the Revolution, and the Old Regime in French AntiSemitism and Durkheim's Sociology, in: Sociological Theory 29,4 (2011), p. 248-271; Pierre Birnbaum, The Anti-Semitic Moment: A Tour of France in 1898. Translated by Jane Marie Todd, New York 2003; Steven Englund, Illusionary Violence: Another Look at the French Antisemitic "Riots" of 1898, in: Stefanie Schüler-Springorum/Michael Kohlstruck/Ulrich Wyrwa (ed.), Bilder kollektiver Gewalt - Kollektive Gewalt im Bild: Annäherungen an eine Ikonographie der Gewalt. Für Werner Bergmann zum 65. Geburtstag, Berlin 2015, S. 219-228.

7 Marcel Stoetzler, Moritz Lazarus und die liberale Kritik an Heinrich von Treitschkes liberalem Antisemitismus; in: Hans-Joachim Hahn/Olaf Kistenmacher (ed.), Beschreibungsversuche der Judenfeindschaft (Europäisch-jüdische Studien. Beiträge, 20), Berlin/Boston 2014, p. 98-120; Mathias Berek, Neglected German-Jewish Visions for a Pluralistic Society: Moritz Lazarus, in: Leo Baeck Institute Year Book 60 (2015), p. 45-59. 
ploying key aspects of his sociology in hands-on combat. ${ }^{8}$ It is important to note, though, that even this key text in the struggle with antisemitism does not even mention either Jews or antisemitism but discusses and defends one of the categories that reactionary, antisemitic Kulturkritik attacked: modern individualism.

From the perspective of a history of sociological responses to antisemitism, the most obvious German counterpart to Durkheim's L'individualisme et les intellectuels would be Lazarus' 1880 anti-antisemitic intervention, Was heißt national?, 'What does national mean?'9 In this chapter I will explore a less obvious cross-border (non-)connection that is closer in terms of its contemporaneity: I will try to bring Durkheim's 1898 text into a dialogue with a lecture by Lazarus' much better known student, Georg Simmel, from 1896, Das Geld in der modernen Cultur, 'Money in Modern Culture"10, that contains key ideas of his later monograph, the Philosophy of Money. ${ }^{11}$ This text does not explicitly contain anything on antisemitism, either, but I would like to suggest that these sociological classics can be read as responses to the type of reactionary critique of modern civilization that underlies the antisemitism of for example the anti-Dreyfusards and their counterparts in Germany.

Talking about Durkheim and Simmel in the same breath is rather tempting also because they lived such parallel lives. Both were born in 1858, although at very different places: Durkheim in the provincial town of Epinal in the Vosges, Simmel in Berlin. Durkheim was the son of a rabbi and abandoned his own initial plan to study for the rabbinate in favour of philosophy. Simmel was a Protestant of Jewish family background and also was primarily trained in philosophy; his father was an industrialist. Both died quite young in 1917 and 1918 respectively. Both were Kantians of sorts, although Durkheim was also influenced by Comte, Simmel, very different, by Bergson. Durkheim's principal objective was to develop a 'science of morality' adequate to the society of the Third Republic to

8 Emile Durkheim, L'individualisme et les intellectuels, in: Emile Durkheim: La Science Sociale et L'Action (Le sociologue, 18), Paris 1970, p. 261-278; Idem, Individualism and the Intellectuals, in: Steven Lukes, Durkheim's 'Individualism and the Intellectuals', in: Political Studies 18 (1969), p. 14-30, here p. 19-30; Emile Durkheim, Individualism and the Intellectuals, in: Robert N. Bellah (ed.), Emile Durkheim on Morality and Society. Selected Writings (The Heritage of Sociology), Chicago 1973, p. 43-57.

9 Stoetzler, The State, the Nation, and the Jews (see note 5); Stoetzler, Moritz Lazarus (see note 7); Berek, Neglected German-Jewish Visions (see note 7).

10 Georg Simmel, Das Geld in der modernen Kultur, in: Heinz-Jürgen Dahme/David P. Frisby (ed.), Georg Simmel. Aufsätze und Abhandlungen 1894-1900 (Gesamtausgabe, 5), Frankfurt a. M. 1992, p. 178-196; Georg Simmel, Money in Modern Culture, in: David Frisby/Mike Featherstone (ed.), Simmel on Culture. Selected Writings (Theory, Culture \& Society), London 1997, p. 243-255.

11 Georg Simmel, The Philosophy of Money, ed. by David Frisby, translated by David Frisby and Tom Bottomore, London ${ }^{3} 2004$. 
which the 'science of social facts' was to provide crucial fundaments and support. One formative influence in Durkheim's intellectual development was a visit to Germany in 1885/6 (after he had already written several reviews of works by German sociologists) that resulted in his long essay on La science positive de la morale en Allemagne. ${ }^{12}$ In this essay he discussed positively the historism of Gustav Schmoller and praised Adolph Wagner's 'organic' concept of society. The fact that Wagner was a leading antisemite Durkheim either failed to pick up at this point, or must have found irrelevant. In spite of his own (comparatively mild) antisemitic tendencies, ${ }^{13}$ Schmoller was an early supporter of Simmel's career: Simmel studied in the environment that the young Durkheim found rather attractive. In 1889 Simmel gave a talk on The Psychology of Money, which later fed into "Money in Modern Culture", in Schmoller's seminar on political economy. Simmel's early development was shaped decisively by Moritz Lazarus, a pioneer of what is now cultural anthropology, which was also an emerging interest of Durkheim. From Lazarus, Simmel learned what Adorno later recognized as his most important contribution, the "return of philosophy" to concrete subjects, things, rather than systemic speculation. ${ }^{14}$ Lazarus had been a crucial figure in the Berlin Jewish community and, not unlike Durkheim, a 'community spokesman' and organizer of the struggle against antisemitism. Durkheim and Simmel were in 1896 and 1898 respectively at pivotal points in their careers: each had published several well-respected books, and they were both in the process of re-focusing their attention in preparation of what would emerge as their 'later', and perhaps most influential, works. Moreover, both saw each other as close allies in the project of forming "une sociologie vraiment scientifique"15, and Simmel had contributed, following Durkheim's invitation, one of the two programmatic articles in the first issue of Année sociologique in 1898 whose editorial board he was a member of. Simmel was removed, though, from the editorial board after the first issue due to Durkheim's disapproval of passages in Simmel's manuscript that concerned two subjects, Zionism and the concept of honourpassages which Durkheim cut without Simmel's agreement. Firstly, Durkheim did not welcome any mentioning of Zionism in the journal as he feared due to his own Jewishness he would automatically be perceived as a supporter of it. Sec-

12 Emile Durkheim, La science positive de la morale en Allemagne, in: Revue Philosophique 24 (1887), p. 33-284; Robert Alun Jones, The Positive Science of Ethics in France. German Influences on De la division du travail social, in: Sociological Forum 9/1 (1994), p. 37-57.

13 Erik Grimmer-Solem, "Every True Friend of the Fatherland." Gustav Schmoller and the “Jewish Question" 1916-1917, in: Leo Baeck Institute Year Book 52/1 (2007), p. 149-163.

14 Theodor W. Adorno, Henkel, Krug und frühe Erfahrung, in: Rolf Tiedemann (Hg.), Theodor Adorno. Gesammelte Schriften, Bd. 11: Noten zur Literatur, Frankfurt a. M. 2003, p. 556-566.

15 Ottheim Rammstedt, Das Durkheim-Simmelsche Projekt einer "rein wissenschaftlichen Soziologie” im Schatten der Dreyfus-Affäre, in: Zeitschrift für Soziologie 26/6 (1997), p. 444. 
ondly, Simmel provided a 'formal' analysis of honour as an entirely socially constituted, content-wise nearly arbitrary means by which social circles maintain their exclusivity, and it seems Durkheim feared this-very typically Simmelian-'formal-sociological' analysis could undermine the Dreyfusard defence of the captain's honour. Although arguably Simmel's position is not incompatible with Durkheim's in theory, in the specific circumstances Durkheim as editor preferred to provoke Simmel's departure: la sociologie vraiment scientifique had to take a back seat when there was reason to fear it might interfere with pressing political necessities. Nevertheless, Durkheim and Simmel continued to communicate as friends and colleagues, and in particular Simmel's work on the sociology of religion was of great influence on Durkheim's later Les formes élémentaires de la vie religieuse. ${ }^{16}$

Individualism and the Intellectuals was Durkheim's intervention in the Dreyfus affair in the period immediately following Emile Zola's famous piece J'accuse in early 1898 when 'the affair' took on increasingly broader dimensions and more general relevancy as an exemplary instance of the struggle over the right-wing assault on the modern, secular French republic. This is probably the one text that comes closest to being an explicit engagement with antisemitism from within the canon of classical, pre-WW1 sociology. ${ }^{17}$

Like On the Psychology of Money of 1889, Simmel's "Money in Modern Culture" of 1896 was an important step in the process of his developing the key ideas in his landmark "Philosophy of Money" of 1900. Although Simmel was-very different in this respect to Durkheim-decidedly and deliberately 'unpolitical', my proposition in this chapter is that Simmel's text can be read as much as Durkheim's as a refutation of antisemitic reasoning-although there are no grounds to argue that Simmel 'intended' it to be such —and that it provides an at

16 Rammstedt, Durkheim-Simmelsche Projekt (see note 15), p. 448.

17 See also Durkheim's short text Anti-Semitism and Social Crisis. Emile Durkheim, AntiSemitism and Social Crisis. Translated by Chad Alan Goldberg, in: Sociological Theory 26/4 (2008), p. 321-323. This is not a developed theoretical text but a short occasional piece. Nevertheless, it clearly indicates a 'Durkheimian' theoretical perspective on antisemitism. Durkheim chooses a national frame of interpretation, opposing German and Russian antisemitisms which are "chronic," "traditional," and "aristocratic" to French antisemitism which "constitutes an acute crisis, due to passing circumstances" (Durkheim, Anti-Semitism and Social Crisis, p. 322). In France, it is the "superficial symptom of a state of social malaise": "when society suffers, it needs someone to blame," and it "naturally" uses "pariahs" "whom opinion already disfavors" as "expiatory victims." Durkheim adds that "secondary circumstances may have played a role," including "certain failings of the Jewish race." These are not in fact causes, though, as they are "compensated by incontestable virtues," and anyway, "the Jews lose their ethnic character with extreme rapidity." The issue is a "serious moral disturbance" that cannot be eradicated in the short term, but the government can remind the public of its morality by "repress[ing] severely all incitement to hatred" and by "enlightening the masses" (Durkheim, Anti-Semitism and Social Crisis, p. 323). 
least equally confident defense of modern, liberal civilization to Durkheim's, while also sharing some of its ambiguities.

\section{Durkheim's Individualism and the intellectuals}

Durkheim's Individualism and the Intellectuals was a response to the article Après le Procès by Ferdinand Brunetière, ${ }^{18}$ a highly regarded literary critic and anti-Dreyfusard, that in turn had been a reaction to Zola's J'accuse and the Manifesto of the intellectuals organized around the same time by a group of scholars and writers. ${ }^{19}$ Brunetière's article had made the points that at least 'some Jews' contributed to the emergence of antisemitism through the dominant role they allegedly played in French society and that the army was a keystone of social cohesion and national unity, and not as Herbert Spencer had it an anachronistic survival of barbarism in the age of industry and commerce. It culminated in a polemic against pompous intellectuals who spread individualism and anarchy, undermining the authority of army and state. Brunetière was a philosophical rationalist who had been seen as an exponent of the positivistic tendency in literary criticism, treating literary history as an evolutionary process, ${ }^{20}$ and was famous for his attacks on what he saw as Zola's 'scientific materialism'. He had already been the focus of a momentous debate when he denounced in an article of 1895 the materialistic spirit of modern science, ${ }^{21}$ advocating the alignment of science with religion. Around this time he had become an admirer of Pope Leo XIII whose Thomism and accommodationist approach to the modern world — such as in the 1891 encyclical Rerum Novarum - must have helped make the notion of a synthesis of Comtean positivism and Catholicism that was then common on the French right more plausible. Brunetière's position resonates with Comte's own attacks on individualism, although in Comte's case these had been part of an anti-Protestant, rather than an anti-Jewish agenda.

Durkheim's rejoinder to Brunetière is written in the spirit of what I suggest was the alternative synthesis of positivism with Kantian idealism. At the level of the intended meaning, it is obvious that Durkheim argued against clericalism and in defence of the republic's professed commitment to 'the ideas of 1789', whose Aufhebung-realization-cum-overcoming-positivism aimed to be. A reader who looks for the ambivalences, contradictions and fissures in the text

18 Ferdinand Brunetière, Après le Procès, in: Revue des Deux Mondes 146 (1898), p. 428-446.

19 Steven Lukes, Durkheim's 'Individualism and the Intellectuals', in: Political Studies 18 (1969), p. $14-30$.

20 Elton Hocking, Ferdinand Brunetière. The Evolution of a Critic (University of Wisconsin Studies in Language and Literature, 36), Madison 1936, p. 6, 37.

21 Hocking, Brunetière (see note 20 ), p. 6. 
will find most interesting, though, to what extent the overlap between the two perspectives produces ambiguities in Durkheim's position that mirror those in Brunetière's. To put it bluntly, the question is, how 'conservative' is Durkheim's republicanism, and how 'liberal' is Brunetière's antisemitism? It is evident that not only 'individualism' but also 'positivism' mean in this context different things to different people. Durkheim's effort in this text to clarify his understanding of the concept of 'individualism' arguably resulted from his own awareness of the ambiguities involved.

Durkheim states that the contributions by Zola and Brunetière have shifted the debate from one of facts about Dreyfus to one of 'principle' and then picks one of the issues addressed by Brunetière: the relationship between individualism and the nation. He eloquently bypasses the issue that lies at an intermediate level between a discussion of facts and one of principles, namely the antisemitic character of the Dreyfus affair, which Brunetière had discussed in the first of three sections of his Après le Procès. Durkheim implies therewith that he understands the rejection of the individualism of 'the intellectuals' who are said to be arrogant enough to question the reasoning of state and military hierarchy to be at the heart of the antisemitism of the anti-Dreyfusards. He responds to the denunciation of the 'intellectuals' and their individualism as hostile to state and nation by turning the accusation on the accuser: not individualism but those who denounce it are anti-national. To this purpose he constructs a concept of individualism that is, in the methodological sense of the term, non-individualistic: not only is individualism, like any other social fact, constituted by society, but it is also, for France at least, the decisive social fact that makes the national society cohere.

Durkheim presents his principal argument right at the beginning of the text, after the two introductory paragraphs: "a first ambiguity," "une première équivoque," needs to be cleared up before all else:

"In order to prosecute individualism more easily, it has been confused with the narrow utilitarianism and the utilitarian egoism of Spencer and the economists. [...] It is indeed an easy game to denounce as an ideal without grandeur this mean commercialism which reduces society to nothing more than a vast apparatus of production and exchange, and it is exceedingly clear that all social life would be impossible if there did not exist interests superior to the interests of the individuals. Nothing is more deserved than that such doctrines are treated as anarchistic, and we can shake hands on this issue." 22

22 "Pour faire plus facilement le procès de l'individualisme, on le confond avec l'utilitarisme étroit et l'égoïsme utilitaire de Spencer et des économistes. [...] On a beau jeu, en effet, à dénoncer comme un idéal sans grandeur ce commercialisme mesquin qui réduit la société à n'être qu'un vaste appareil de production et d'échange, et il est trop clair que toute vie commune est impossible s'il n'existe pas d'intérêts supérieurs aux intérêts individuels. Que 
The handshake offered by Durkheim is underwritten by the shared Comtean anti-individualism that Durkheim modifies through his conception of a quasisolidaristic form of, as it were, politically correct individualism that has gone through a Kantian-idealist reformulation. Durkheim goes on to argue that the anti-Dreyfusards attack the anarchistic-economistic-Spencerian concept of individualism in bad faith: they must know that it is an irrelevancy not even held by many economists anymore. Durkheim probably had in mind here the $\mathrm{Ka}$ theder-socialists of the 'historical school' around Schmoller whose historicist rejection of rationalism he had applauded earlier. ${ }^{23}$ Durkheim argues that the anti-Dreyfusards really attack what he proposes is the actual individualism prevalent in the French Republic which is idealist rather than utilitarian. Durkheim adds that their putting raison d'état above the inviolable rights of an individual (such as Dreyfus) to fair legal process is in fact akin to the utilitarian doctrine of the greatest happiness of the greatest number which likewise fails to acknowledge the inviolability of individual human rights.

By contrast, the Kantian idealist individualism defended by Durkheim is one to which a notion of the generically human is sacred:

“Whoever makes an attempt on a man's life, on a man's liberty, on a man's honor, inspires in us a feeling of horror analogous in every way to that which the believer experiences when he sees his idol profaned. Such an ethic $[. .$.$] is a religion in which man$ is at once the worshipper and the god. [...] This religion is individualistic [...]."24

Durkheim claims that individualism in this sense is not only 'a' sort of religion but it is 'the' religion for the modern period: "Not only is individualism distinct from anarchy, but it is henceforth the only system of beliefs which can ensure the moral unity of the country." 25 It is a "truism" that "only a religion can bring about this harmony." However, "it is known today that a religion does not necessarily

de semblables doctrines soient traitées d'anarchiques, rien donc n'est plus mérité et nous y donnons les mains." Durkheim, L'individualisme et les intellectuels (see note 8), p. 262; Durkheim, Individualism and the Intellectuals [Lukes] (see note 8), p. 20; Durkheim, Individualism and the Intellectuals [Bellah] (see note 8), p. 44.

23 A more thorough discussion would need to examine to what extent Spencer himself and the tradition of classical political economy in fact subscribed to the bogeyman concept of individualism that Brunetière and Durkheim construct.

24 'Quiconque attente à une vie d'homme, à la liberté d'un homme, à l'honneur d'un homme, nous inspire un sentiment d'horreur, de tout point analogue à celui qu'épreuve le croyand qui voit profaner [sic] son idole. Une telle morale [...] est une religion dont l'homme est, à la fois, le fidèle et le Dieu. [...] cette religion est individualiste [...]"; Durkheim, L'individualisme (see note 8), p. 265; Durkheim Individualism, Lukes (see note 8), p. 20f; Durkheim, Individualism, Bellah (see note 8), p. 46.

25 'Non seulement l'individualisme n'est pas l'anarchie, mais c'est désormais le seul système de croyances qui puisse assurer l'unité morale du pays"; Durkheim, L'individualisme (see note 8), p. 270; Durkheim Individualism [Lukes] (see note 8), p. 25; Durkheim, Individualism, Bellah (see note 8), p. 50. 
imply symbols and rites, properly speaking, or temples and priests"26: "essentially, it is nothing other than a body of collective beliefs and practices endowed with a special authority." This authority results from the fact that "as soon as a goal is pursued by an entire people, it acquires, in consequence of this unanimous adherence, a sort of moral supremacy" and "a religious character." Durkheim recuperates therewith the concept of the religious from his opponents, along with that of the national, arguing that individualism "has penetrated our institutions and our customs, it has become part of our whole life, [...] our entire moral organization," that is, it is central to French national culture and society. ${ }^{27}$

Durkheim writes that "all that societies require in order to hold together is that their members fix their eyes on the same end and come together in a single faith." ${ }^{28}$ This faith, to Durkheim, is individualism; if some misuse individualism for egoistic ends, this proves nothing against it.

It is worth noting that Durkheim presupposes in this argument the existence of 'a people' (peuple) that is able unanimously to pursue a shared goal. This presupposition is reflected in the immediately following statement, introduced with "from a different angle," that for "a society" (clearly used here synonymous with 'a people') to be coherent (i. e., to define and 'unanimously' to pursue goals) there needs to exist "a certain intellectual and moral community." Durkheim's gloss on the 'truism' is rather circular: religion (broadly understood) is needed to warrant moral unity, but religion is also the result of common goal-oriented action of 'a people' that in turn presupposes the moral unity that it is supposed to warrant. The most stable category in this argument is actually the one that is least explicated, the 'people'.

Of religion Durkheim goes on to say that it always changes so that "the religion of yesterday could not be the religion of tomorrow." He then asks the question what new religion can replace the old one which Brunetière and others are artificially trying to resurrect. Durkheim's argument is here that "the only possible [religion] can only be the religion of humanity, of which the individualistic ethic is the rational expression." Here Durkheim switches from an idealist-normative argument to a positivistic-factual one: he presents what actually is a (perfectly valid) liberal, Kantian-idealist normative claim—we ought

26 Durkheim, L'individualisme (see note 8), p. 270 f; Durkheim Individualism, Lukes (see note 8), p. 25; Durkheim, Individualism, Bellah (see note 8), p. 51.

27 "Il a pénétré nos institutions et nos mœurs, il est mêlé à toute notre vie [...] toute notre organisation morale"; Durkheim, L'individualisme (see note 8), p. 265; Durkheim Individualism [Lukes] (see note 8), p. 22; Durkheim, Individualism [Bellah] (see note 8), p. 46.

28 "[...] tout ce qu'il faut aux sociétés pour être cohérentes, c'est que leurs membres aient les yeux fixés sur un même but, se rencontrent dans une même foi [...]"; Durkheim, L'individualisme (see note 8), p. 268; Durkheim Individualism [Lukes] (see note 8), p. 24; Durkheim, Individualism [Bellah] (see note 8), p. 49. 
to promote individualism as the only form of quasi-religion that modern society needs-as if it was a conclusion arrived at by way of empirical observation: individualism positively is the religion of modern society. This move transforms the normative-idealist demand into a scientific insight in the law-like necessity of a historical reality that one should not oppose, which is in keeping with the Comtean conception of what sociology ought to do: understand the laws of history so as to adapt human agency to them and sail with their winds. Durkheim's argument here is that societies grow and expand, circumstances become more diverse and more mobile, and hence traditions and social practices need to "maintain a state of plasticity and instability," while advanced division of labour also diversifies the contents of men's minds: "the members of a single social group will no longer have anything in common other than their humanity." The "idea of the human person (personnne humaine) in general," although it is "given different nuances according to the diversity of national temperaments," is "therefore the only idea which would survive, unalterable and impersonal, above the changing tides of particular opinions," 29 and "the sentiments which it awakens are the only ones to be found in almost all hearts":

"The communion of spirits can no longer be based on definite rites and prejudices, since rites and prejudices have been swept away by the course of events. Consequently, nothing remains which men can love and honor in common if not man himself. That is how man has become god for man and why he can no longer create other gods without lying to himself. [...] The whole of individualism lies here; and that is what makes it a necessary doctrine." ${ }^{30}$

Durkheim's argument not only collapses a normative argument into an empirical one-the universalist, liberal normative ideal is posited as if it was a 'necessary' social reality anyway-but is also empirically dubious: 'general humanity' is regrettably not at all the only thing modern individuals acknowledge they share with others. Durkheim's claim that individualism and the 'religion of humanity' by necessity must become the only possible quasi-religion in the modern context is a nonsequitur, and a normative, not to say rather wishful thought. His further claim that "if there is one country among all others in which the individualist cause is truly national, it is our own" is likewise a claim that the

29 Durkheim, L'individualisme (see note 8), p. 271 f; Durkheim Individualism [Lukes] (see note 8), p. 26; Durkheim, Individualism [Bellah] (see note 8), p. $51 \mathrm{f}$.

30 "La communion des esprits ne peut plus se faire sur des rites et des préjugés définis puisque rites et préjugés sont emportés par le cours des choses; par suite, il ne reste plus rien que les hommes puissent aimer et honorer en commun, si ce n'est l'homme lui-même. Voilà comment l'homme est devenu un dieu pour l'homme et pourquoi il ne peut plus, sans se mentir à soi-même, se faire d'autres dieux. [...] Tout l'individualisme est là; et c'est là ce qui en fait la doctrine nécessaire"; Durkheim, L'individualisme (see note 8), p. 272; Durkheim Individualism [Lukes] (see note 8), p. 26; Durkheim, Individualism [Bellah] (see note 8), p. 52. 
Dreyfus affair itself disproved. Durkheim's key argument that the unfair treatment of Dreyfus constitutes an unpatriotic act rests on rather shaky foundations: Durkheim fails to give a compelling reason why, as the anti-Dreyfusards believe, nationalism, antisemitism or Catholicism, or a combination of all these could not just as well, or even more effectively, fulfil the function of being the 'religion' required by modern society. A century and a bit later, with the resurgence of religious 'fundamentalisms' of all sorts that are in practice strongly political affirmations of religion, it seems not too far-fetched to conclude that quite often religion is the 'religion' of modern society.

Durkheim's agreement with the anti-Dreyfusards that societal cohesion must be warranted by some sort of religion would only work as the basis of an antiantisemitic argument if he was able to offer robust support for his claim that only "individualism properly understood" (to use the term Tocqueville coined in a related context) can be that religion. Durkheim is in breach here of one of his own justly celebrated methodological premises: just because it is functionally and logically needed by society, it will not necessarily come about. There is much in Durkheim's argument that Brunetière and other anti-Dreyfusards could adopt without needing to come to the anti-antisemitic conclusion that Durkheim suggests follows from it.

\section{Simmel's Money in modern culture}

Simmel's 1896 lecture Money in modern culture ${ }^{31}$ starts from a reflection on modernity (Neuzeit) in contradistinction to the Middle Ages: while "in the Middle Ages a human being finds himself in compulsory membership (bindender Zugehörigkeit) of a village (Gemeinde) or an estate, a feudal association or a corporation," 32 modernity, on the one hand, has given the personality "incomparable inner and outer freedom of movement," on the other it has given "equally incomparable objectivity" to "the material (sachliche) contents of life" to the effect that "the things' own laws (die eigenen Gesetze der Dinge) increasingly assert themselves (gelangen mehr und mehr zur Herrschaft)" as objective laws-a notion that is not a million miles from Durkheim's concept of the faits sociaux. Simmel describes the contradictory effects of "the money economy" that he finds central to the modernization process and plays out its positive and negative effects against each other, ending on a religious note in a (perhaps

31 Simmel, Das Geld in der modernen Kultur (see note 10), p. 178-196; Simmel, Money in modern culture (see note 10), p. 243-255.

32 Simmel, Das Geld in der modernen Kultur (see note 10), p. 178; Simmel, Money in modern culture (see note 10), p. 244. 
surprising) effort to reconcile the contradictions that his lecture takes account of. The fact that Simmel puts money rather than, say, 'division of labour' or 'mode of production' at the centre of the modernization process puts his argument in direct competition with the Kulturkritik type of literature of the time, including many antisemitic tracts, that tend to point to money as the root of all the evils of modern civilization. Simmel poses the question, here as elsewhere in his work, how evil money really is. Although there is no evidence that Simmel deliberately 'intended' to confront that literature, it seems reasonable to assume that his choice of focus reflects a certain spirit of the time to the effect that Simmel's argument on money and modernity can also be read as an anti-antisemitic argument, albeit in a more indirect fashion than Durkheim's.

One of the main lines of reasoning in Simmel's lecture is that 'the money economy' enhances independence and autonomy of the person and thus is a precondition of modern individualism in Durkheim's sense, but also makes possible new forms of unity. For example the "enormous successes" of modern trade unions have been made possible by the neutrality of money that "eliminates everything personal and specific" and unites people impersonally for a course of action. "Thus when one laments the alienating and separating effect of monetary transactions, one should not forget" that money "creates an extremely strong bond among the members of an economic circle": money always "points to other individuals," so that "the modern person is dependent on infinitely more suppliers and supply sources than was the ancient Germanic freeman or the later serf." 33 Simmel asserts that money "establishes incomparably more connections among people than ever existed in the days of feudalism or arbitrary unification (gewillkürten Einung) that the guild romantics (Associations-Romantiker) most highly celebrate." ${ }^{\prime 34}$ Simmel makes quite explicit here whom he argues against: those who lament alienation, celebrate ancient Germanic or other village communal life, Associations-Romantiker. Simmel defends here modern forms of association against Gemeinschaft (community)-style arguments. His argument differs markedly from the way in which Durkheim for example sought inspiration from medieval corporations for his proposition to create intermediary institutions between state and individual in the concluding chapter of $L e$ Suicide $^{35}$ and most famously in the 1902 preface to the second edition of De la division du travail social. ${ }^{36}$

33 Simmel, Das Geld in der modernen Kultur (see note 10), p. 182; Simmel, Money in modern culture (see note 10), p. 246.

34 Simmel, Das Geld in der modernen Kultur (see note 10), p. 183; Simmel, Money in modern culture (see note 10), p. 246.

35 Emile Durkheim, On Suicide. A Study in Sociology, New York 1997.

36 Emile Durkheim, Preface to the Second Edition. Some Remarks on Professional Groups, 
At the same time, Simmel seems to accept as valid many objections to modern culture that would also be put forward by romantic Kulturkritik such as that money produces alienation along with autonomy. Simmel makes a two-pronged argument: "the conversion of a possession into money" is experienced as a liberation, as the value of that possession is not anymore "captured in one particular form" and can subsequently take any arbitrary form, but it also produces "a vapidity of life and a loosening of its substance." ${ }^{37}$ Simmel relates to this "the restlessness and the dissatisfaction of our times":

"The qualitative side of objects lose their psychological importance through the money economy; the continuously required estimation in terms of monetary value eventually causes this to seem the only valid one; more and more quickly one lives past the specific meaning of things that cannot be expressed in economic terms. Its revenge, as it were, is that dark, so very modern feeling that the core and meaning of life slips through our fingers again and again, that definite satisfactions become ever rarer, that all the effort and activity is not actually worthwhile." ${ }^{38}$

Equivalence with money devalues even "objects themselves.” Money is common; only the individual is noble; ${ }^{39}$ because money is equal to many things, it "pulls the highest down to the level of the lowest." Simmel backs up this argument with a sentence that could be straight out of any kulturpessimistische polemic against democracy: it is "the tragedy of every levelling process that it leads directly to the position of the lowest element. For the highest can always descend to the lowest, but anything low seldom ascends to the highest level."

The main theoretical point of Simmel's lecture is that the ever increasing range of means that lead to more means complicate modern life and push life's goals ever further out of sight, culminating in that universal means, money. Due to its universality and ubiquity, Simmel argues, one "cannot ignore the frequent lament that money is the God of our times." This formulation goes back to Heinrich Heine who added (in the thirty-second dispatch of Lutetia) that

in: Steven Lukes (ed.), Emile Durkheim. The Division of Labor in Society, New York 2014, p. 8-32.

37 Simmel, Das Geld in der modernen Kultur (see note 10), p. 186; Simmel, Money in Modern Culture (see note 10), p. 248.

38 "Die qualitative Seite der Objecte büßt durch die Geldwirthschaft an psychologischer Betonung ein, die fortwährend erforderliche Abschätzung nach dem Geldwerthe läßt diesen schließlich als den einzig gültigen erscheinen, immer rascher lebt man an der spezifischen, ökonomisch nicht ausdrückbaren Bedeutung der Dinge vorüber, die sich nur durch jene dumpfen, so sehr modernen Gefühle gleichsam rächt: daß der Kern und Sinn des Lebens uns immer von neuem aus der Hand gleitet, daß die definitiven Befriedigungen immer seltener werden, daß das ganze Mühen und Treiben doch eigentlich nicht lohne."; Simmel, Das Geld in der modernen Kultur (see note 10), p. 186; Simmel, Money in Modern Culture (see note 10), p. 248-249.

39 Simmel, Das Geld in der modernen Kultur (see note 10), p. 187; Simmel, Money in Modern Culture (see note 10), p. 249. 
"Rothschild is his prophet." In Heine, though, this was not a kulturkritischer 'lament' but a sarcastic comment on James Rothschild's conspicuous wealth and in particular the exaggerated respect paid to him by the ordinary mortals who visited him in his Paris office. ${ }^{40}$ Half a century later, in the different context of Simmel's day, this much-quoted formulation had indeed become a 'lament' and had acquired a well-established antisemitic subtext, and this seems to be what Simmel is pointing to.

Simmel explores the homology of money and God in several directions in his effort to understand what makes it so plausible: God is, according to Nicholas of Cusa, "the coincidentia oppositorum," which means that "all the varieties and contrasts of the world reach unity in Him"; the idea of God and, even more so, "the idea that we possess Him" creates a rich mixture of feelings of peace and security, and the "feelings stimulated by money have a psychological similarity to this in their own arena." As the "equivalent of all values," it "becomes the centre in which the most opposing, alien and distant things find what they have in common and touch each other." ${ }^{11}$ Money, like God, grants "elevation over the individual" and inspires "trust in its omnipotence." Like magic, it can conjure up those lower, particular objects at any given moment by re-metamorphosing into them:

"This feeling of security and calm which the possession of money provides, this conviction of possessing in it the intersection of all values, constitutes psychologically, or, as it were, formally, the point of comparison that gives the deeper justification to that complaint about money as the God of our times." ${ }^{\prime 2}$

Simmel indicates here that in spite of its antisemitic subtext he aims not to dismiss the kulturkritische 'lament' but tries to discover its 'deeper' meaning.

Next, Simmel argues that the money economy makes modern life both abstract and petty: it necessitates "continuous mathematical operations in everyday life," including the necessity constantly to reduce "qualitative values to quantitative ones" and a new extent of "exactness, sharpness and precision," but also allows to calculate differences in value down to the penny, resulting in a

40 Heinrich Heine, Sämtliche Werke, vol. 4: Schriften zu Literatur und Politik II, Vermischtes, Munich 1972, p. 250.

41 Simmel, Das Geld in der modernen Kultur (see note 10), p. 192; Simmel, Money in modern culture (see note 10), p. 252.

42 "Diese Sicherheit und Ruhe, deren Gefühl der Besitz von Geld gewährt, diese Ueberzeugung, in ihm den Schnittpunkt der Werthe zu besitzen, enthält so rein psychologisch, sozusagen formal, den Gleichungspunkt, der jener Klage über das Geld als den Gott unserer Zeit die tiefere Bedeutung giebt." Simmel, Das Geld in der modernen Kultur (see note 10), p. 192; Simmel, Money in modern culture (see note 10), p. 252. 
rather petty mentality. ${ }^{43}$ Likewise, the "fact that people carry around small denominations of money in their pockets" allows them anytime to purchase "all sorts of small articles, often on a whim," increasing frivolity and a "petty style" of life. " 44 "The objective and indifferent character" with which money "offers itself" to "the highest and the lowest actions" also induces ethical laxity:

"Persons who are otherwise honest may participate in the most shady kinds of deceitful 'promotions', and many people are likely to behave more unconscientiously and with more dubious ethics in money matters than elsewhere." ${ }^{35}$

The use of the term "promotions" (Gründungen) in this passage seems to be a reference to the discourse on the so-called Gründerschwindel, a staple of the antisemitic literature of the 1870s in particular, when the economic crisis of 1873 to 1875-dubbed Gründerkrach-was linked to the collapse of risky and sometimes fraudulent enterprises which in turn were blamed by antisemites on Jewish involvement.

Simmel concludes his lecture by emphasising that "the money economy" is internal to and a product of modern culture as a whole:

"The monetary system [is] a branch from the same root that produces all the other flowers of our culture, [and] one can take consolation from this against the complaints raised particularly by the preservers of spiritual and emotional values against the auri sacra fames and the devastation wrought by the financial system. The closer our understanding comes to that root, the more apparent must become the relations between the money economy to not only the dark sides but also to the subtlest and highest aspects of our culture. Thus, like all great historical forces, the money economy might resemble the mythical spear that is itself capable of healing the wounds it inflicts." ${ }^{46}$

Ending on this Rousseauean note, Simmel rules out a rejection of modernity and the "money economy" that he sees as its defining feature as only modernity can

43 Simmel, Das Geld in der modernen Kultur (see note 10), p. 192; Simmel, Money in modern culture (see note 10), p. 253.

44 Simmel, Das Geld in der modernen Kultur (see note 10), p. 192; Simmel, Money in modern culture (see note 10), p. 253.

45 "So haben sich Personen von sonstiger persönlicher Ehrenhaftigkeit an den dunkelsten 'Gründungen' betheiligt, und viele Menschen verfahren eher in reinen Geldangelegenheiten gewissenloser und zweideutiger, als daß sie in anderen Beziehungen sittlich Zweifelhaftes thäten."

46 "Das Geldwesen [ist] ein Zweig der gleichen Wurzel, die alle Blüthen unserer Kultur treibt, [und man mag] daraus einen Trost gegenüber den Klagen schöpfen, die gerade die Pfleger der geistigen und gemüthlichen Güter über die Auri sacra fames und über die Verwüstungen des Geldwesens erheben. Denn je mehr die Erkenntniß sich jener Wurzel nähert, desto ersichtlicher müssen die Beziehungen der Geldwirthschaft, wie zu den Schattenseiten, so doch auch zu dem Feinsten und Höchsten unserer Kultur hervortreten, so daß es, wie alle großen geschichtlichen Mächte, dem mythischen Speer gleichen mag, der die Wunden, die er schlägt, selbst zu heilen im Stande ist." Simmel, Das Geld in der modernen Kultur (see note 10), p. 196; Simmel, Money in modern culture (see note 10), p. $254 \mathrm{f}$. 
right modernity's wrongs. Simmel adds that "the formation of economic life [...] receives its character from the great uniform trends of historical life, whose ultimate sources and motives in turn are the divine secret (das göttliche Geheimniß)." ${ }^{37}$ Although it is important to recognise that Simmel formulates here an argument against anti-modern Kulturkritik, the rather cheesy metaphysical 'consolation' he offers is unlikely to impress many of those who feel driven towards it by the uglier sides of modernity and the "money economy."

Both Simmel and Durkheim similarly try to square the circle of defending modern society while accepting quite a few of the kulturkritische 'laments' about modernity also shared by antisemites. These include the notion that it is characterised by 'Spencerian' egotism, the abstract and soulless mechanics of the economic, and a 'sacred' greed for material wealth all of which they argue need to be opposed. Durkheim chiefly works with a dichotomy of idealist versus utilitarian notions of individualism, Simmel more dialectically argues that the positive and negative aspects of modernity are inseparably interwoven with each other. Both suggest, though, that modernity's sunny side is bound to prevail, which Simmel suppurts by appealing to a straightforwardly metaphysical notion of a 'divine secret', while Durkheim, in good positivist fashion recoiling from such open admission of reliance on non-sociological reasoning, suggests that there are positive, socio-historical reasons why modern society not only needs, but by necessity also must and will produce the non-egotistical form of individualism.

Both interventions in their own right are highly instructive and fascinating when discussed in their respective historical contexts but appear in retrospect as forms of whistling in the dark, albeit formulated eloquently and in good faith. Both are equally and in combination, though, part of the intellectual culture that from a perspective post-Holocaust must be said to have failed. No other perspective is available, though: we are condemned to working within and with the debris of the civilization that brought about and was undone, but not terminated, by the Holocaust. History has made historicism irrelevant: we do not have the luxury of taking our viewpoint from anywhere other than a dismal and disillusioned present. Social theory must deal seriously and robustly with reactionary critiques of modern capitalist civilization, including its own blind spots and ambiguities lest it be, at best, ineffective in the struggle against, at worst, recuperated by, the enemy. The right-wing critique of civilization can only be defeated through a critique of the civilization modern humans have created that turns its emancipatory promises against its failure to deliver them. As in the texts by Durkheim and Simmel discussed in this chapter, critical study of classical

47 Simmel, Das Geld in der modernen Kultur (see note 10), p. 196; Simmel, Money in modern culture (see note 10), p. $254 \mathrm{f}$. 
sociological theory can discover elements of such critique as well as the limits of a (post-) Enlightenment that was cut short. ${ }^{48}$

48 I am taking my cue here from the position developed by Horkheimer and Adorno, most eminently in their 1947 book, Dialectic of Enlightenment. On this see Marcel Stoetzler, 'It only needs all': re-reading Dialectic of Enlightenment at 70, openDemocracy (June 24, 2017), URL: $<$ https://www.opendemocracy.net/can-europe-make-it/marcel-stoetzler/it-only-needs-allre-reading-dialectic-of-enlightenment-at-70> (last access April 28, 2018); 'Dialectic of Enlightenment. Philosophical Fragments', in: Beverly Best/Werner Bonefeld/Chris O'Kane (eds.), 2018, The SAGE Handbook of Frankfurt School Critial Theory, vol. 1, 142-160 and 'Wer aber von der Geschichte des Subjekts nicht reden will, sollte auch vom Kapitalismus schweigen. Zur Radikalität der Dialektik der Aufklärung', in: Gunzelin Schmid Noerr/EvaMaria Ziege, eds., 70 Jahre Dialektik der Aufklärung, Springer (in press). 
Rezeption, Transfer und Vergleich /

Reception, Transfers, and Comparison 
Open-Access-Publikation im Sinne der CC-Lizenz BY 4.0

(c) 2019, V\&R unipress $\mathrm{GmbH}$, Göttingen 